\title{
Урожайность и качество картофеля зависят от технологии
}

\section{С.В. Мальцев, В.Н. Зейрук, К.А. Пшеченков, А.В. Смирнов}

Отражены результаты исследований различных способов подготовки дерново-подзолистой суглинистой почвы и внесения минеральных удобрений, обеспечивающие высокую урожайность и качество картофеля при выращивании в Центральном регионе России. Предложена технология, при применении которой урожайность картофеля в опыте достигла 54,2 т/га, суммарные повреждения клубней не превышали 9,7\%, а лежкость картофеля при длительном хранении была не ниже 95,0\%.

Ключевые слова: картофель, система обработки почвы, урожайность, минеральные удобрения, расход ГСМ, картофелеуборочный комбайн, лежкость клубней.

П одготовка почвы, особенно суглинистой,- один из наиболее энергоемких процессов при выращивании картофеля, на выполнение которого требуются значительные затраты горюче-смазочных материалов, цена на которые постоянно растет $[1,2,3]$. С другой стороны, растет цена и на минеральные удобрения, стоимость которых при разбросном способе внесения в дозе 800-1000 кг/га в физическом весе, составляет в настоящее время от 18-22 тыс. р/га. Меньшие затраты дает способ локального внесения сажалкой при посадке, или в гребни при их предпосадочной нарезке [4].

В связи с этим, цель работы - установить оптимальное сочетание системы обработки почвы и способа внесения минеральных удобрений, обеспечивающих их выполнение с минимальными затратами при условии выращивания высоких урожаев картофеля, минимальной повреждаемости клубней при уборке и высокой их лежкости при длительном хранении

В течение 2012-2018 годов мы проводили исследования по определению влияния технологии подготовки почвы и междурядной обработки на урожайность картофеля и качество работы комбайна при уборке при выращивании на суглинистой почве в условиях Центрального региона России (КХ «Нива», Тейковский район Ивановской области). Исходя из того, что картофель - культура рыхлой почвы (оптимальная плотность

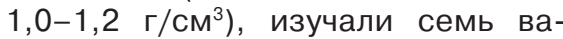
риантов подготовки почвы от мак- симальной до минимальной и два варианта междурядной обработки - один с применением орудий с активными рабочими органами, второй с пассивными. Варианты обработки почвы сочетались со способами внесения минеральных удобрений - локально сажалкой при посадке и в гребни при их предварительной нарезке (диаммофоска по 400 кг/га в физическом весе). В варианте внесения удобрений вразброс перед перепашкой зяби доза составляла 800 кг/га в физическом весе. Предшественник - озимые зерновые [5, 6].

Схема исследований состояла из двух опытов (табл. 1). Опыт 1 включал осеннюю (зяблевую) обработку и весеннюю (предпосадочную) обработку с применением орудий с активными и пассивными рабочими органами. В опыте 2 - осеннюю обработку не проводили, а только весенняя (предпосадочная)

В вариантах 1, 2 и 6 кроме сплошного предпосадочного фрезерования почвы на глубину 12-14 см применяли формирование гребней по всходам фрезерным гребнеобразователем с последующей обработкой через неделю поверхности гребней гербицидом Зенкор. В вариантах 3, 4, 5, 7 - два довсходовых боронования сетчатой бороной, навешенной на культиватор КОН-2,8 ПМ с одновременным рыхлением междурядий и окучиванием для исключения извлечения клубней на повер-

\section{Таблица 1. Наименование операций по вариантам исследований}

\begin{tabular}{l|l} 
Вариант & \multicolumn{1}{c}{ Опыт } \\
Осенняя обработка & Опыт 1 \\
Предшественник - озимые зерновые. Осенняя подготовка - общая для вариантов 1-5: лу- \\
щение стерни лемешным лущильником на глубину 16-18 см и зяблевая вспашка оборот- \\
ным плугом на глубину 25 см в агрегате с трактором 1221 «Беларусь»
\end{tabular}

$$
\text { Весенняя обработка (предпосадочная) }
$$

1

Фрезерование на глубину 12-14 см, нарезка гребней с внесением минеральных удобрений 400 кг/га физического вещества (Ф.в.), посадка без внесения минеральных удобрений

Фрезерование на глубину $12-14$ см, посадка по ровной пашне с локальным внесением минеральных удобрений 400 кг/га ф.в.

3 Культивация на глубину 15-17 см, посадка по ровной пашне с локальным внесением минеральных удобрений 400 кг/га ф.в.

4 Нарезка гребней с локальным внесением минеральных удобрений $400 \mathrm{kr} / г а$ Ф.в., посадка по гребням без внесения удобрений

Внесение минеральных удобрений 800 кг/га ф.в. вразброс, перепашка зяби оборотным плугом на глубину 25 см, посадка по ровной пашне без внесения удобрений

Опыт 2

В этом варианте опыта проводили только весеннюю (предпосадочную) обработку почвы

Культивация на глубину 15-17 см, фрезерование на глубину 12-14 см, посадка по ровной пашне с внесением минеральных удобрений 400 кг/га ф.в. Культивация на глубину 15-17 см, посадка по ровной пашне с внесением минеральных удобрений 400 кг/га Ф.в. 
Таблица 2. Урожайность, расход топлива, суммарная стоимость машин и расчетная прибыль по вариантам исследований, 2012-2018 годы

\begin{tabular}{|c|c|c|c|c|c|c|c|}
\hline \multirow{2}{*}{ Наименование показателя } & \multicolumn{7}{|c|}{ Варианты } \\
\hline & 1 & 2 & 3 & 4 & 5 & 6 & 7 \\
\hline Урожайность, т/га & 45,7 & 39,9 & 41,4 & 54,2 & 51,3 & 43,7 & 44,5 \\
\hline $\begin{array}{l}\text { Расход топлива на подготовку почвы, нарезку гребней, посадку, } \\
\text { внесение удобрений вразброс, междурядную обработку, л/га }\end{array}$ & 95,0 & 85,0 & 82,0 & 76,0 & 101,0 & 71,0 & 49,0 \\
\hline Всего расход топлива на технологию выращивания и уборку, л/га & 229,5 & 219,0 & 216,0 & 210,0 & 235,0 & 205,0 & 183,0 \\
\hline Стоимость топлива, тыс. p/га & 8,0 & 7,7 & 7,6 & 7,4 & 8,2 & 7,2 & 6,4 \\
\hline Суммарная стоимость машин, тыс. р/га & 25,4 & 25,4 & 21,8 & 21,8 & 22,3 & 24,4 & 11,5 \\
\hline Общие затраты на выращивание и уборку картофеля, тыс. р/га & 191,2 & 190,9 & 187,1 & 186,9 & 195,7 & 189,3 & 175,7 \\
\hline Стоимость товарного урожая, тыс. р/га & 411,0 & 365,0 & 367,0 & 504,0 & 467,0 & 398,0 & 406,0 \\
\hline Прибыль, тыс. p/га & 219,0 & 174,0 & 179,0 & 317,0 & 270,0 & 208,0 & 219,0 \\
\hline Снижение прибыли по отношению к четвертому варианту, \% & 31,0 & 45,0 & 43,0 & 0,0 & 15,0 & 34,0 & 31,0 \\
\hline
\end{tabular}

хность, поскольку во всех вариантах глубина посадки не превышала 6-8 см. По всходам проводили обработку тем же набором рабочих органов, что и при довсходовой обработке. Перед смыканием ботвы проводили глубокое рыхление междурядий ярусными стрельчатыми лапами с одновременным окучиванием трехъярусными стрельчатыми окучниками. Гербициды не применялись. При предпосадочной нарезке гребней удобрения подавались лотковым тукоприводом открытого типа в раствор двухъярусной лапы на глубину 14-15 см. Гребни формировали трехъярусными стрельчатыми окучниками, чем обеспечивалось сплошное рыхление почвы. При локальном внесении сажалкой удобрения располагаются на дне борозды вместе с клубнями, т.е. на глубине 6-8 см, тогда как при внесении в гребни между высаживаемыми клубнями и удобрениями образуется прослойка почвы слоем 7-9 см, в связи с чем к моменту проникновения к ним корневой системы они растворяются под действием почвенной влаги и лучше усваиваются по сравнению с внесением сажалкой, когда они находятся почти на поверхности вместе с клубнями. В опытах картофель сажали четырехрядной сажалкой КСМ-4А с междурядьями 70 см при густоте 45 тыс. шт/ га. Сорт ранний, отечественной селекции - Удача. В качестве критериев оценки технологий подготовки почвы были приняты урожайность, суммарная стоимость машин, расход горючего, качество работы комбайна при уборке, расчетная прибыль [7].

Кроме урожайности, определяли также некоторые качественные показатели клубней - содержание сухого вещества, крахмала, редуцирующих сахаров, устойчивость мякоти клубней к потемнению и их лежкоспособность. Также определяли грануло- метрический состав почвы в гребнях к уборке и экономическую эффективность по вариантам исследований

Содержание в гребнях мелкой фракции размером менее 20 мм было примерно на одинаковом уровне - 82,6-84,8\% за исключением пятого варианта с перепашкой зяби, на котором оно было на уровне $78 \%$.

Эффективность различных вариантов системы обработки почвы и внесения минеральных удобрений под картофель представлена в табл. 2.

В вариантах 1 и 2, в которых применяли сплошное предпосадочное фрезерование почвы на глубину 12-14 см и формирование гребней по всходам (голландская технология) фрезерным гребнеобразователем и в варианте 6, в котором применялось фрезерование почвы после культивации, урожайность снизилась по сравнению с четвертым вариантом на 9-14 т/га. Это объясняется такими факторами, как образование плотной корки на вершинах гребней, задерживающей появление всходов в случае выпадения обильных осадков следом за формированием гребней. Кроме того, в процессе вегетации при выпадении осадков на вершинах гребней образуются глубокие продольные трещины, снижающие урожайность и вызывающие позеленение части клубней, что недопустимо при выращивании продовольственного картофеля [8].

Наибольшая прибыль в размере 317 тыс. р/га получена в четвертом варианте. Для дополнительной проверки эффективности нарезки гребней с одновременным внесением минеральных удобрений, был проведен опыт выращивания картофеля с его применением при минимальной обработке почвы - весенняя культивация на глубину 15-17 см с посадкой по гребням без внесения удоб- рений. Урожайность составила 52,9 т/га с расходом топлива меньше на 17,0 л/га по сравнению с четвертым вариантом и на 41,0 л/га по сравнению с пятым.

При уборке картофеля комбайном «AVR Spirit 6200» с боковым подкопом, чистота клубней в бункере составляла по вариантам 89,3$91,1 \%$. На пятом варианте - 88,3\%. Суммарные повреждения клубней колебались от 9,7 до 11,6\%, т.е. были близки по вариантам.

Содержание сухого вещества и крахмала в клубнях колебалось по вариантам незначительно в пределах 1,5-2,0\% и находилось на уровне, соответственно, $16-18 \%$ и 10-12\%. Содержание редуцирующих сахаров, оказывающее существенное влияние на цвет обжаренных продуктов, зависело в большей степени от погодных условий в период вегетации года [9]. Так, в 2012, 2014 и 2017 годах, отличающихся повышенным выпадением осадков и пониженной температурой воздуха, оно составляло от 0,9-1,5\% в зависимости от варианта при допустимом по требованиям содержании не более 0,3\%. В 2013 году (более теплом и сухом) этот показатель был на уровне 0,05-0,2\%. Устойчивость к потемнению мякоти вареных клубней также больше зависела от погодных условий периода вегетации, чем от технологии подготовки почвы. В 2012 и 2014 годах она была низкой, в 2013 году - мякоть практически не темнела.

Потери при длительном хранении при температуре $3-4{ }^{\circ} \mathrm{C}$ по всем вариантам исследований не превышали 5\% [10].

На основании результатов исследований рекомендуется выращивать картофель на суглинистых почвах в Центральном регионе России по технологии, включающей осеннюю обработку почвы - лущение стерни или куль- 
тивацию при других предшественниках, вспашку на глубину пахотного горизонта оборотным плугом, весной предпосадочную нарезку гребней по зяби с одновременным локальным внесением минеральных удобрений (диаммофоска, нитрофоска и др.) на глубину 14-15 см в дозе 400-450 кг/га в физическом весе с подачей их с помощью открытого лоткового тукопровода в раствор двухрядной лапы и формированием гребней трехъярусными окучниками из стрельчатых лап, обеспечивающих в совокупности сплошное рыхление почвы, посадку сажалкой упрощенной конструкции типа КСПГ-4, довсходовую и послевсходовую междурядную обработку орудиями с пассивными рабочими органами. При такой технологии урожайность картофеля достигает 54,2 т/га, суммарные повреждения клубней не превышают 9,7\%, а лежкость картофеля при длительном хранении не ниже $95,0 \%$.

\section{Библиографический список}

1.Пшеченков К.А., Мальцев С.В. Технология посадки картофеля // Картофель и овощи. 2008. № 2. С. 9-10. 2.Верещагин Н.И., Пшеченков К.А. Комплексная механизация возделывания, уборки и хранения картофеля. М.: Колос, 1977. 351 с.

3.Пшеченков К.А., Колчин Н.Н., Мальцев С.В. Технологии и средства механизации для уборки и послеуборочной доработки картофеля // Картофель и овощи. 2012. № 5. С. 8-10.

4.Федотова Л.С., Зеленов Н.А. Удобрение как фактор высокой производительности и качества картофеля. М., 2007. $180 \mathrm{c}$

5.Пшеченков К.А., Мальцев С.В. Состояние и перспективы совершенствования посадки картофеля на суглинистых почвах // Вестник Рязанского государственного агротехнологического университета им. П.А. Костычева. 2017. № 4 (36). С. 108-113.

6.Пшеченков К.А., Смирнов А.В. Оптимизация технологии подготовки почвы и способа внесения минеральных удобрений под картофель // Достижения науки и техники АПК. 2016. № 3. С. 17-18.

7.Машинные технологии и техника для производства картофеля / С.С. Туболев, С.И. Шеломенцев, К.А. Пшеченков, В.Н. Зейрук. М.: Агроспас, 2010. 311 с.

8.Мальцев С.В., Пшеченков К.А. Диагностика развития растений картофеля в период вегетации // Защита картофеля. 2011. № 2. С. 26-28.

9.Результаты испытания сортов картофеля селекции ВНИИКХ / К.А. Пшеченков, С.В. Мальцев, В.И. Седова, А.Э. Шабанов // Картофель и овощи. 2010. № 8. С. 4-6.

10.Пшеченков К.А., Зейрук В.Н., Мальцев С.В. Период покоя клубней и определяющие его факторы // Защита и карантин растений. 2007. № 8. С. 54-55.

\section{Об авторах \\ Мальцев Станислав \\ Владимирович (ответственный за} переписку), канд. с. - х. наук, с.н.с. E-mail: stanmalcev@yandex.ru

Зейрук Владимир Николаевич, доктор с. - х. наук, зав. лабораторией защиты картофеля

\section{Пшеченков Константин}

Александрович, доктор техн. наук, профессор, руководитель группы хранения и переработки картофеля Смирнов Андрей Вячеславович, аспирант

ФГБНУ «Всероссийский научно-ис- следовательский институт картофельного хозяйства имени А.Г. Лорха»

Influence of soil tillage system and methods of mineral fertilizers application on yield, quality of

harvesting and storability of potatoes S.V. Maltsev (author for correspondence), $P h D$, senior research fellow.

E-mail: stanmalcev@yandex.ru

V.N. Zeiruk, DSc, head of potato protection laboratory

K.A. Pshechenkov, DSc, prof., head of group of storage and processing of potatoes

A.V. Smirnov, post-graduate student Russian research institute of potato farming by A.G. Lorh

Summary. The article reflects the results of studies of various methods of preparation of sod-podzolic loamy soil and application of mineral fertilizers that ensure high yield and quality of potatoes when grown in the Central region of Russia. The technology is proposed, in the application of which the yield of potatoes in the experiment reached $54,2 t /$ ha, the total damage to tubers did not exceed $9,7 \%$, and the maturation of potatoes during long-term storage was not lower than $95,0 \%$.

Keywords: potatoes, tillage system, yield, fertilizers, fuel consumption, potato harvester, storability of tubers.

\section{Органическое овощеводство - первые шаги развития}

Более 70 человек приняли участие в научно-практическом семинаре «Органическое земледелие: путь к здоровью и долголетию» в учебном центре Агрохолдинга «Поиск».

В крупнейшем российском селекционно-семеноводческом Агрохолдинге «Поиск» прошло уникальное мероприятие. На одной площадке собрались ученые, бизнесмены, фермеры, занимающиеся экологическим земледелием.

Агрохолинг «Поиск», как компания, оперативно реагирующая на современные вызовы, решила организовать живое обсуждение, где представители науки, бизнеса и производства, занятые в органическом сельском хозяйстве, могли бы услышать друг друга и наметить пути дальнейшей работы. Это не первое специальное мероприятие в рамках подпрограммы, которую компания реализует с научными и производственными партнерами. Системная работа началась два года назад, а последнее обсуждение было в сентябре этого года на Дне поля в ЗАО «Куликово».

Открыл мероприятие член совета директоров Агрохолдинга «Поиск», канд. с.-х. наук С.В. Максимов. Он отметил, что в Европе интерес к органическому земледелию насчитывает не одно десятилетие, в России же это важное направление только начинает свой путь, и мы тоже должны делать хотя бы первые небольшие шаги на этом пути.

По словам члена совета директоров Агрохолдинга «Поиск», канд. с.-х. наук Н.Н. Клименко, тема семинара полностью соответствует миссии компании, которую она успешно выполняет - «селекция вкусных и полезных овощей для здоровья и долголетия». Более того, компания взяла на себя функцию организатора совместной работы по разработке технологий выращивания органических овощей на авторских сортах и гибридах. Компания много лет ведет селекцию сортов и гибридов, совместимых с биологическими методами их выращивания.

На семинаре выступили также: исполнительный директор Национального органического союза О.В. Мироненко, начальник отдела селекции и первичного семеноводства Агрохолдинга «Поиск», канд. с.-х. наук А.Н. Ховрин, директор ФНЦО, д-р с.-х. наук, член-корр. РАН А.В. Солдатенко, канд. биол. наук, зав. лабораторией генетической коллекции томатов С.Н. Нековаль, научный сотрудник ФГБУ «ВНИИКР» М.А. Савушкин, основатель органического хозяйства «Биофема Кубани» С.А. Воданюк, С.Б. Бабенко, главный агроном ООО «Биотехагро», Г.Н. Мулярчик, председатель ООО «МФК Опора», а также агрономы и фермеры, занимающиеся органическим земледелием в своих хозяйствах. Докладчики представили последние научные разработки и методики для биологической защиты растений, достижения селекции овощных культур на повышенную питательную ценность и пониженное содержание вредных веществ, технологии органического производства. Отметили они и важность законодательного регулирования в этой области.

Семинар показал, что, несмотря на новизну для нашей страны, спрос на органическую продукцию в России существует, а значит, должно быть и предложение. Агрохолдинг «Поиск», в полном соответствии со своей миссией, готов принять в развитии этого направления самое деятельное участие. 